\title{
Influence of Flipped Classroom Model on Korean Language Learners' Achievement - Focused on Beginner Level ${ }^{1}$
}

\section{翻转课堂模式对韩语初学者学习效果的影响}

\author{
Arum Kim 金美丽*
}

$\mathrm{T}$

HIS paper describes a structured attempt to integrate the flipped

classroom pedagogical model into language classrooms. The purpose of this study is to examine the possible impacts of flipped classroom strategies on Korean language learners' academic performance, specifically their listening and speaking abilities. Adopting a quasiexperimental design, two different formats for flip teaching were developed in this study. The results indicate that the flipped classroom was a more effective instructional design than the non-flipped classroom in both academic outcomes and the development of listening and speaking abilities. Given the positive results, this paper concludes with a call for more research into this promising pedagogy to contribute to its knowledge base across disciplines.

本文描述了将翻转课堂教学模式整合到语言课堂的尝试, 目的 是研究翻转课堂策略对韩语学习者学习表现的影响, 特别是对听说 能力的影响。本研究采用准实验设计, 开发了两种不同的翻转教学 形式, 激励学生主动学习。结果表明, 翻转课堂对学生的学术表现 和听说能力的发展比非翻转课堂更有效。鉴于取得了积极成果, 本 文最后呼吁对这一有前景的教学法进行更多研究, 进一步补充其跨 学科研究的知识基础。

\footnotetext{
${ }^{1}$ This paper was presented at the 23rd International Conference on ISO and TQM (ICIT) held at UIC in May 2019 and won the Best Paper.

本文系2019年5月在北师港浸大举行的第23届ICIT国际会议最佳论文获奖作品。
} 


\section{Introduction}

Teaching techniques have evolved over the past decades to adapt to the way students learn new material. The learning model known as the 'flipped classroom' is one of the developing theories in education and has attracted the attention of many researchers and educators worldwide (Bergman and Sams, 2012). The flipped classroom can be viewed as a pedagogical approach to blended learning techniques in which the typical activities of the classroom lecturer followed by homework in traditional teaching procedures are reversed in order, and often supplemented or integrated with instructional videos (Khan, 2012;

Tucker, 2012).

While the term flipped classroom is relatively new in education, it is not a fundamentally novel teaching method (Berrett, 2012). Over the past decade, a number of corresponding terms, such as inverted classroom (Lage and Platt, 2000), just-in-time teaching (Novak, 2011), flipped classroom (Bergmann and Sams, 2012), and inverted learning (Davis, 2013), have been presented in the literature to describe this evolving method or approach, which encourages student preparation before class.

The flipped classroom was developed by American educators Jonathan Bergmann and Aaron Sams in 2000 (Bergmann and Sams, 2012). The idea of this technology is that the main stages of the teaching and learning process and homework are reversed. To begin, teachers adopting a flipped classroom approach can convert traditional face-to-face lectures into narrated PowerPoint videos, create instructional videos using any lecture capture tools, or select ready-made educational videos from websites or networks for learners to study prior to class as lecture replacements. Classroom activities, therefore, are devoted to fulfilling practical tasks based on the educational content provided beforehand, as well as discussion with the teacher about main points or issues encountered with the work.

One of the benefits often cited for the flipped classroom is that students are given more opportunities to develop higher order thinking under teacher guidance and with peer support as needed (Berrett, 2012). Students receive immediate and thorough feedback on material from their teacher instead of attempting the work at home and failing to complete the work due to missed information or lack of understanding. The reduction of face-to-face didactic learning (traditional learning) prompts students to research and learn by other means, such as collaborative work or peer instruction in the classroom (Gilmartin and Moore, 2010). In addition, at home, students can pause and rewind lectures, seek out answers, and review any information that they do not understand (Bergmann and Sams, 2012). 
Given the prospect for flipped classroom approaches to enhance lecture delivery, STEM disciplines (i.e., science, technology, engineering, and mathematics) that are traditionally taught deductively with a heavy reliance on lecturing, appear to have received the most attention among early adopters of flip teaching at universities (see examples of a biology course in Marrs and Novak, 2004; a Microsoft Excel course in Davies, Dear, and Ball, 2013; a statistics course in Strayer, 2012). These studies have generally reported the educational value of flip teaching in relation to enhanced class preparation, increased classroom interactivity, and improved academic performance.

By contrast, the use of lectures for transmitting knowledge tends to be of little significance to humanities disciplines that commonly favor inductive teaching methods to encourage students to assimilate information and construct knowledge. This may explain in part why the flipped classroom approach, featuring lecture enhancement, has attracted relatively less interest among educational researches in the field of humanities.

Accordingly, in the field of language education, little or no research (especially experimental design research) to date has rigorously studied how flipped language classroom teaching can enhance student learning.

Hence, the present study sets out to flip the classroom for Korean language learners at a university in China to examine its pedagogical potential in language education as a means of contributing to the growing line of research on flip teaching. The research questions that guided this work are as follows: (1) How did the flipped classroom influence the students' academic performance? (2) How did the flipped classroom influence the students' listening and speaking ability?

\section{Methodology}

\subsection{Research design}

This study adopted a posttest-only quasiexperimental design to examine the impacts of flipped classroom teaching on student learning, with a specific focus on engaging students in the flipped classroom through an active learning strategy. The independent variable was the flipped classroom approach with two different formats of instructional design: structured units of flipped classroom in the form of 'Lecturer made videos' (experimental group) and non-flipped classroom conducted in a relatively traditional manner (control group). The dependent variables were the students' academic performance, which were measured four times throughout one semester.

This study was carried out over a period of 14 weeks and divided into three major phases, including (1) a preparation phase for technology orientation, (2) an instruction phase to facilitate implementation of the 
flipped classroom, and (3) an evaluation phase for overall assessment of teaching and learning.

The structured flipped classroom was

\section{specifically set out for the experimental} group with 'Lecturer made videos.' A total of 12 videos were produced by the lecturer before the start of semester and these were uploaded onto a class web page. The condition created for the control group was the non-flipped classroom that adopted task-based learning activities in class and assigned homework to be completed in a conventional manner. Unlike the experimental groups that incorporated elearning materials, the learning materials delivered to the control group were in the traditional print format, although the content for both groups remained identical. That is, the two conditions differed only with regards to the structure and delivery of the respective learning materials, as well as the ways in which these materials were used to support teaching and learning.

\subsection{Participants}

The participants of the study $(\mathrm{N}=72)$ were recruited from three intact classes of foreign language learners taking a Korean 1 at a Chinese university. The students enrolled in this course met weekly for three 50-minute class periods. Most participants were firstor second-year students from different majors, aged 18-20 years old, and who had never learned Korean before. None of the participants had any flipped classroom experiences prior to this study.
Table 1. Participant information

\begin{tabular}{|c||c|c|c|c||c|c|}
\hline \multicolumn{1}{|c||}{ Group } & \multicolumn{3}{c||}{ Academic Year } & \multicolumn{2}{c|}{ Male / Female } \\
\cline { 2 - 7 } & 1 & 2 & 3 & 4 & Male & Female \\
\hline $\begin{array}{c}\text { Experimental Group } \\
(\mathrm{N}=24)\end{array}$ & 8 & 15 & 0 & 1 & $4(16.6 \%)$ & $20(83.4 \%)$ \\
\hline $\begin{array}{c}\text { Control Group } \\
(\mathrm{N}=48)\end{array}$ & 3 & 13 & 0 & 0 & $20(41.6 \%)$ & $28(58.4 \%)$ \\
\hline
\end{tabular}

\subsection{Data collection}

This course concluded with an assessment which was designed to evaluate students' comprehension of the learning materials and their overall task performance. The course assessments were supplied four times over the semester (including an oral test, mid-term exam, speaking and writing assessment, and final exam) and consisted of four types of language abilities, which included listening, speaking, reading, and writing. The summed scores of each assessment were then used as a measure of the academic performance variable in the statistical analysis.

The students' oral test and speaking and writing assessment were reviewed independently by the course lecturer, using a rubric designed by the university's language department. The mid-term and final exams were designed using multiple choice questions, short answers, long answers, and essay writing in a conventional manner.

Each assessment had a different weighting that amounted to a total of 100 points. The oral test was given 10 points (10\%), midterm exam was given 20 points (20\%), writing and speaking assessment was given 
15 points (15\%), and the final exam was given 40 points (40\%). Participation (15\%) was not considered for students' academic performance in this study.

\section{Results and Analysis}

\subsection{Academic learning outcomes resulting from the flipped classroom}

The study's first research question sought to determine whether the flipped classroom impacted the students' academic performance in any way, using the four assessments (oral test, mid-term exam, speaking and writing assessment, and final exam) as the primary measurement. Table 2 provides descriptive statistics of each group's course assessments and summarizes the group's results to compare the participants' quality of academic performance in this study. T-test analyses of variance were performed to examine any differences in academic learning outcomes due to the varying approaches or structured attempts to flip the classroom. Some differences in the mean scores of assessments were found between two groups, but no significant differences were found.

The experimental group's academic learning outcomes were more positive than the control group in all assessments except the oral test. Of note, the score differences between the two groups increased over the semester. For example, the difference of the mid-term exam results was 1.7 points, but the difference of the
Table 2. Comparison of group differences on academic performance

\begin{tabular}{|c|c|c|c|c|c|}
\hline Assessments & Group & Mean & SD & $F$ & $p$ \\
\hline \multirow{2}{*}{$\begin{array}{l}\text { Oral test } \\
\text { (10 point) }\end{array}$} & experimental & 9.4 & 0.83 & \multirow{2}{*}{.016} & \multirow{2}{*}{.747} \\
\hline & control & 9.5 & 1.38 & & \\
\hline \multirow{2}{*}{$\begin{array}{l}\text { Mid-term exam } \\
\text { (20 point) }\end{array}$} & experimental & 15.8 & 3.81 & \multirow{2}{*}{1.238} & \multirow{2}{*}{.090} \\
\hline & control & 14.1 & 4.29 & & \\
\hline \multirow{2}{*}{$\begin{array}{l}\text { Assignment } \\
\text { (15 point) }\end{array}$} & experimental & 13.7 & 1.39 & \multirow{2}{*}{.200} & \multirow{2}{*}{.872} \\
\hline & control & 10.7 & 1.22 & & \\
\hline \multirow{2}{*}{$\begin{array}{l}\text { Final exam } \\
\text { (40 point) }\end{array}$} & experimental & 32.1 & 8.01 & \multirow{2}{*}{.845} & \multirow{2}{*}{.168} \\
\hline & control & 28.9 & 9.12 & & \\
\hline \multirow{2}{*}{$\begin{array}{l}\text { Sum score } \\
\text { (85 point) }\end{array}$} & experimental & 71.0 & 14.25 & \multirow{2}{*}{.890} & \multirow{2}{*}{.332} \\
\hline & control & 63.2 & 14.36 & & \\
\hline
\end{tabular}

final exam results was 3.2 points, with the experimental group on top. A possible explanation for this may be that the week in which each assessment was taken varied. The mid-term exam was taken in the middle of the semester (8th week), but the final exam was taken at the end of the semester (15th week). Given students generally need time to adapt to a new learning system; it seems that a certain amount of time is needed to maximize the impact of the flipped classroom. As such, it could be predicted that 15 weeks are more meaningful than 8 weeks for adapting to the new system.

With the experimental group scoring higher, it can be assumed that these students had the advantage of repetition and review. The final exam covers all material studied during the semester and is therefore a more demanding task for students. In preparation for the test, students from the experimental group have access to the 'Lecturer made videos,' 
which they can watch multiple times during the semester, if necessary, while the students from the control group relied only on hand-outs or their own notes taken during class. This difference in the learning environment might have caused the greater difference in score between the two groups.

These results reflecting students' academic performance for this study suggest that, in general terms, the structured flipped classroom may better facilitate student learning in coursework compared with the traditional classroom. Although the results are not statistically (ttest) significant across all four assessments, the participants from the structured flipped classroom demonstrated better academic performance.

\subsection{Listening and speaking performance resulting from flipped classroom}

The second research question in the study examined the students' listening and speaking performance in the flipped classroom, as measured by all assessments. For this, the listening and speaking scores were separated from other elements (grammar, vocabulary, essay, etc.). Table 3 provides descriptive statistics of each group's listening and speaking performance and summarizes the comparison of the groups' results to depict the participants' quality of academic performance in this study. T-test analyses of variance were conducted to examine any
Table 3. Comparison of group differences in listening and speaking performance

\begin{tabular}{|c|c|c|c|c|c|}
\hline Assessments & Group & Mean & SD & $F$ & $p$ \\
\hline \multirow{2}{*}{ Oral test } & experimental & 9.4 & 0.83 & \multirow{2}{*}{.016} & \multirow{2}{*}{.747} \\
\hline & control & 9.5 & 1.38 & & \\
\hline \multirow{2}{*}{$\begin{array}{l}\text { Listening in } \\
\text { Mid-term }\end{array}$} & experimental & 4.4 & 1.47 & \multirow{2}{*}{.051} & \multirow{2}{*}{$.012^{*}$} \\
\hline & control & 3.5 & 1.45 & & \\
\hline \multirow{2}{*}{$\begin{array}{l}\text { Speaking in } \\
\text { Assignment }\end{array}$} & experimental & 9.5 & 1.07 & \multirow{2}{*}{.002} & \multirow{2}{*}{$.001^{*}$} \\
\hline & control & 8.6 & 0.97 & & \\
\hline \multirow{2}{*}{$\begin{array}{l}\text { Listening in } \\
\text { Final exam }\end{array}$} & experimental & 6.8 & 1.43 & \multirow{2}{*}{.015} & \multirow{2}{*}{$.012^{*}$} \\
\hline & control & 5.8 & 1.57 & & \\
\hline \multirow{2}{*}{ Sum score } & experimental & 30.1 & 3.81 & \multirow{2}{*}{.001} & \multirow{2}{*}{$.010^{*}$} \\
\hline & control & 27.4 & 4.13 & & \\
\hline
\end{tabular}

differences in listening and speaking performance due to the varying approaches or structured attempts to flip the classroom.

Significant differences in the mean scores of assessments were found between the two groups, and results of t-test analyses also proved that there were significant differences between the two groups, except for those in the oral test. A possible explanation for this might be that the oral test was conducted in the 4th week after the semester had started, so students from the experiment group might not have had enough time to adapt for a new learning system. Another possible explanation for this may be that the oral test was specifically designed to assess students' skills in reading the Korean alphabet; therefore, strictly speaking, this assessment might not be included in the listening and speaking category in a usual classroom scenario.

Judging from the overall result of the 
second research question, it seems that the flipped classroom had a positive influence on students' listening and speaking skills development. The students from the experiment group completed many different activities in their class time instead of studying grammar or memorizing vocabulary. Because of this, the experiment group's students were more exposed to a communication environment using a target language (Korean), especially some grammar elements which they were required to master.

These results regarding student listening and speaking performance suggest that, in general terms, the structured flipped classroom may better facilitate student learning in coursework compared with the traditional classroom. Although significant group differences were not consistently found across all the assessments, the participants from the structured flipped classroom demonstrated better listening and speaking performance.

\section{Conclusion}

The aim of the flipped classroom is to engage students in pre-class study to enhance involvement in class, and ultimately to achieve more satisfying learning outcomes. As an initial effort to flip the language classroom, the research reported here describes: (1) How did the flipped classroom influence the students' academic performance? (2) How did the flipped classroom influence the students' listening and speaking ability? The positive results of this study are thus restricted to the specific research context and technological tools used in the learning environment.

In the overall academic performance, some differences in the mean scores of assessments were found between the two groups, but this result was not statistically significant. In the listening and speaking performance, however, there was a significant difference between the two groups statistically. The positive results of this study are only restricted to the specific research context and technological tools used in the learning environment. Given that the main objective of this study was to experiment with the flipped classroom approach for Korean language learners, the findings from this work are not intended to be generalized due to the limited sample size. Rather, the major strengths of this research will be its scope and instructional design in relation to the use of the flipped classroom approach.

Educators in the twenty-first century are constantly adopting new technologies and pedagogies. Flipped classroom is arguably one of the most promising approaches to transforming learning experiences, with holistic integration of technology and active learning strategies. Future research may build on the lessons learned from this study and further explore the effects of wellstructured versus ill-structured or guided 
versus unguided flipped classroom strategies on student learning, using different instructional design or active learning techniques.

It is suggested that a similar study be conducted on a larger sample size of 30 or more in each group to demonstrate more statistical confidence. A continued suggestion would be an extension of time implementation of the flipped classroom scenario, and studies could also be extended beyond the beginner level to upper levels, with the development of valid assessment measures to observe the influence of the flipped classroom. Finally, variations of this pedagogy in combination with other innovative applications of technology could also contribute to the current knowledge base of the flipped classroom, helping it to grow in both scope and depth. $\mathbb{Z}$

\section{References}

Bergmann, J., Sams, A. (2012). Flip your classroom: Reach every student in every class every day. Eugene, OR: International Society for Technology in Education.

Berrett, D. (2012). How "flipping" the classroom can improve the traditional lecture. The Chronicle of Higher Education, 58(25), pp.16-18.

Davis, C. (2013). Flipped or inverted learning: Strategies for course design. In E. G. Smyth \& J. X. Volker (Eds.), Enhancing instruction with visual media: Utilizing video and lecture capture (pp. 241265). Hershey, PA: IGI Global.

Davies, R.S., Dean, D. L., Ball, N. (2013). Flipping the classroom and instructional technology integration in a college-level information system spreadsheet course. Educational Technology Research and Development, 61(4), pp.563-580.

Gilmartin, M., Moore, N. (2010). Teaching for Better Learning: A Blended Learning Pilot Project with First-Year Geography Undergraduates. Journal of Geography in Higher Education, 34(3), pp.327-344.

Khan, S. (2012). The one world schoolhouse: Education reimagined. London: Hodder and Stoughton.

Marrs, K. A., Novak, G. (2004). Just-in-time teaching in biology: Creating and active learner classroom using the Internet. Cell Biology Education, 3(1), pp.49-61.

Novak, G. M. (2011). Just-in-time teaching. New Directions for Teaching and Learning, 2011(128), pp.63-73.

Strayer, J. F. (2012). How learning in an inverted classroom influences cooperation, innovation and task orientation. Learning Environments Research, 15(2), pp.171-193.

Tucker, B. (2012). The flipped classroom. Education Next, 12(1), pp. 82-83. 